Article

\title{
Fluorescent Pan Traps Affect the Capture Rate of Insect Orders in Different Ways
}

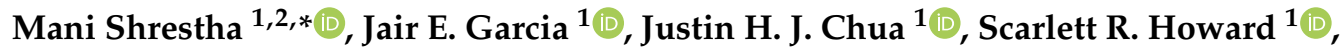 \\ Thomas Tscheulin ${ }^{3}\left(\mathbb{D}\right.$, Alan Dorin ${ }^{2}$, Anders Nielsen ${ }^{4}\left(\mathbb{D}\right.$ and Adrian G. Dyer ${ }^{1,5}$ (D) \\ 1 School of Media and Communication, RMIT University, Melbourne, VIC 3001, Australia \\ 2 Faculty of Information Technology, Monash University, Melbourne, VIC 3800, Australia \\ 3 Laboratory of Biogeography and Ecology, Department of Geography, \\ University of the Aegean University Hill, GR-81100 Mytilene, Greece \\ 4 Centre for Ecological and Evolutionary Synthesis (CEES), Dept. of Biosciences, \\ University of Oslo, P.O. Box 1066 Blindern, 0316 Oslo, Norway \\ 5 Department of Physiology, Monash University, Melbourne, VIC 3800, Australia \\ * Correspondence: sh.mani@gmail.com
}

Received: 6 December 2018; Accepted: 21 January 2019; Published: 1 February 2019

\begin{abstract}
To monitor and quantify the changes in pollinator communities over time, it is important to have robust survey techniques of insect populations. Pan traps allow for the assessment of the relative insect abundance in an environment and have been promoted by the Food and Agricultural Organization (FAO) as an efficient data collection methodology. It has been proposed that fluorescent pan traps are particularly useful, as it has been suggested that they capture high numbers of insects in an unbiased fashion. We use a simultaneous presentation of fluorescent and non-fluorescent pan trap colours to assess how flower-visiting insects of different orders respond to visual stimuli and reveal a significant interaction between trap fluorescence and captured insect type. In particular, Coleoptera (beetles) and Lepidoptera (butterflies and moths) were captured significantly more frequently by fluorescent traps, whilst Dipterans (flies) were captured significantly less frequently by this type of pan trap. Hymenopterans (bees and wasps) showed no significant difference in their preference for fluorescent or non-fluorescent traps. Our results reveal that the use of fluorescent pan traps may differently bias insect capture rates when compared to the typical experience of colour flower-visiting insects in natural environments. Correction factors may, therefore, be required for interpreting insect pan trap data collected with different methodologies.
\end{abstract}

Keywords: urban environment; pan traps; native insects; habitat fragmentation

\section{Introduction}

Several studies have reported that global declines in insect pollinator populations are linked to phenomena including habitat fragmentation, pathogens, invasive species, climate change, and/or the widespread use of agricultural insecticides [1-9]. Understanding the different contributing factors to these potential mechanisms is valuable since about $35 \%$ of food production for human consumption relies on insect pollination [1,10-12], with an estimated value in the range of 235-577 billion US\$/year [12]. It is, thus, important to reliably quantify the relative abundance of potential flower-visiting insects in different environments to assist our understanding of changes in plant pollinator interactions, especially when considering habitat fragmentation caused by urbanization and agricultural intensification $[1,5,7]$. 
Studies and surveys of potential pollinating insects have employed pan traps (also called bowl traps) to estimate flower visitor numbers in a variety of different habitats. Pan traps have been proposed as an efficient method to collect insects from within a habitat with minimum sampling biases [13-24]. Different insect species, however, may present preferences in their perception of different colours [25-30]. For example, bees have trichromatic colour perception with ultraviolet-, blue-, and green-sensitive photoreceptors [31]. Some ants appear to perceive input from two different photoreceptor classes for colour perception [32]. Flies have four colour receptors that are further spectrally tuned with screening pigments $[33,34]$. Butterflies may have four or five photoreceptors that can also be spectrally tuned [33,35-37]. The dimensions of colour vision can dramatically influence how colour choices are made by these different animals $[27,38]$. To attempt to control for potential colour preference biases, previous studies have used differently coloured pan traps such as white, yellow, and blue, as perceived by human colour vision, to quantify the broad insect diversity potentially encountered in ecological settings $[14,16,21,23]$. These studies have typically used UV-fluorescent pan traps based on anecdotal evidence $[39,40]$ that such stimuli collect more insects, although this factor of UV-fluorescence on insect capture rate has, only recently, been subject to formal testing [41].

Fluorescence is the phenomenon by which short wavelength radiation is absorbed by a material and re-emitted as longer wavelength radiation [42]. Materials with fluorescent properties may be of either biological [42] or non-biological origin (e.g., plastics or paints) [43]. For example, the effect is observed when we use UV-black-lights in nightclubs to produce UV-fluorescence from clothing, fluorescent highlighting pens, or Post-It notes (or sticky notes) [42]. Whilst fluorescence may enhance the intensity of a signal from a particular region of the spectrum, its effect typically results in an overall reduction of the total number of photons coming from a surface due to the conversion efficiency of the fluorescent material. Thus, to perceive and potentially benefit from fluorescence, the visual system of the receiver needs to be spectrally tuned to the wavelengths at which the fluorescence is produced [29,42]. Hence, it is reasonable to assume that insects with different visual systems may perceive fluorescent stimuli differently. This could induce sampling bias when using differently coloured pan traps, including the use of fluorescence, to attract insects.

Here, we address the question of whether pan traps displaying fluorescent properties may capture higher numbers of flower-visiting insects than non-fluorescent pan traps. Since Araneae (spiders) were also collected using our method and there is some evidence that spiders can visit flowers to prey on insect pollinators [44,45] or collect nectar [46], and that they are therefore potentially part of an extended pollination network, we also report the capture rate of these arthropods. Further, Orthopterans (crickets) are also included in our current analysis as these insects are pollinators of some flowering plants [47]. In our approach, we used typical colours employed previously for surveying insect populations for ecological studies $[14,16,18,21]$. We aim to test whether fluorescent pan traps catch more or less individuals of different orders of insects in comparison to non-fluorescent traps to inform us about the most effective way to survey potential insect flower visitors while minimising sampling bias.

\section{Materials and Methods}

\subsection{Study Area}

This study was conducted within the grounds of Monash University's Clayton campus in Melbourne, Australia. The university grounds include large areas of remnant native bushland, as well as extensive gardens providing abundant resources to flower-visiting insects. The grounds are located in the temperate zone $\left(37^{\circ} 53^{\prime} \mathrm{S}-37^{\circ} 55^{\prime} \mathrm{S}, 145^{\circ} 06^{\prime} \mathrm{E}-145^{\circ} 08^{\prime} \mathrm{E}\right)$ (Figure 1). In this study, we established five study sites and sampled insects during the Australian summer (January to May 2016) with a temperature range from $17-42{ }^{\circ} \mathrm{C}$. Detailed temperatures for specific dates are available in Table S1. 


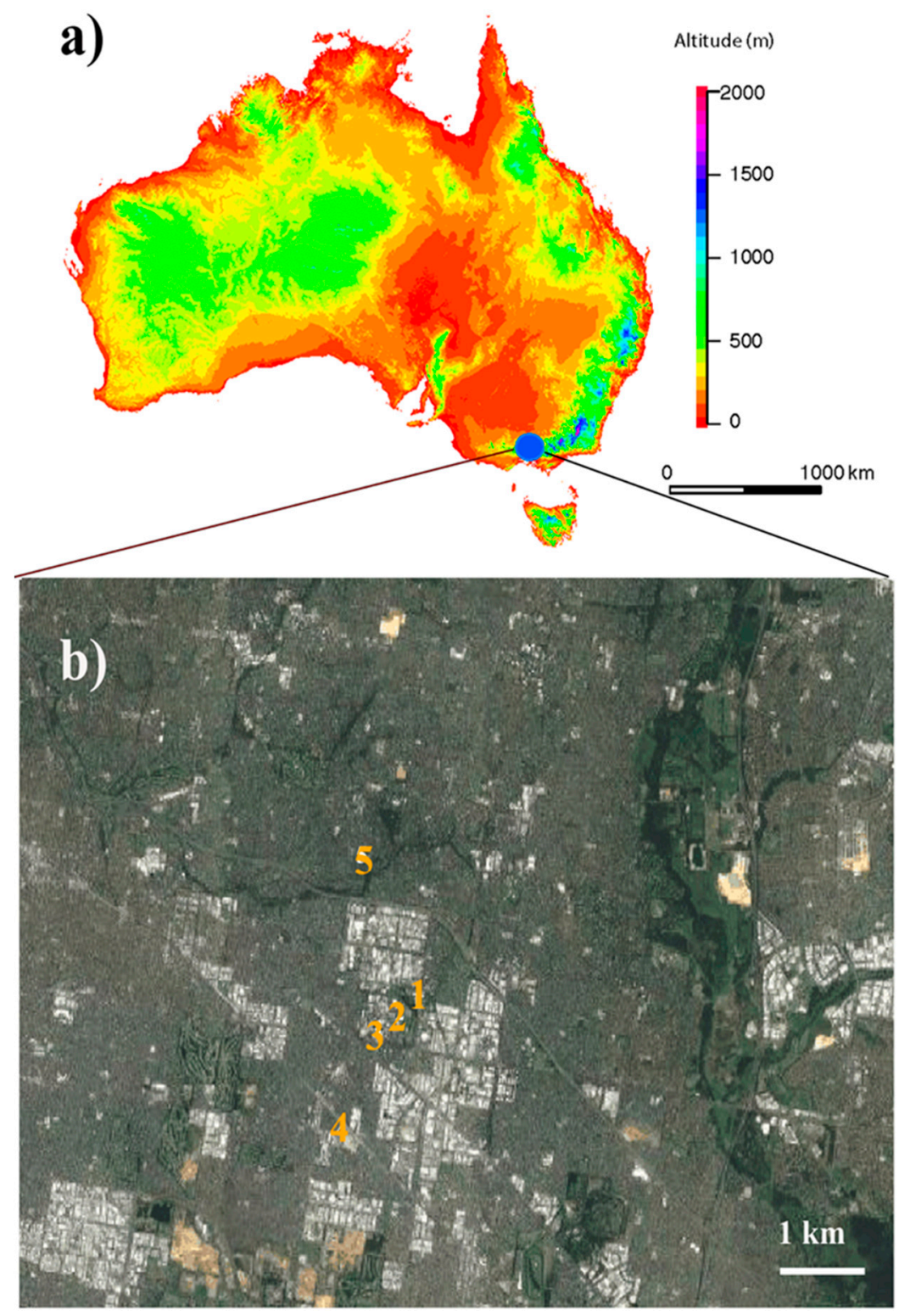

Figure 1. A map of the study area: (a) Map of Australia showing the geographical location of the study sites (blue solid circle) and (b) the numbers on the map show the sampling locations at Monash University, Clayton Campus and its surroundings of Melbourne, Australia. The map was prepared in $R$ version 3.5.1 using packages "maps", "dismo", and "raster" [48] (R core Team 2018).

\subsection{Data Collection}

We installed eight differently coloured pan traps at each site to sample the different groups of potential flower-visiting insects. Pan traps were separated by approximately $25 \mathrm{~cm}$ (Figure 2A) which ensured that successive traps were viewed using colour processing by free flying bees [31]. We used pan trap colours perceived as white, blue, yellow, and green to human vision (Figure 2A). As it is well established that insect colour vision is different to human colour vision, we provide details for each colour stimulus in Table 1 including their spectral reflectance (Figure 2B). Each pan trap cluster ( $n=7$ clusters of pan trap bowls at 5 sites) contained eight plastic soup bowls (ca. $500 \mathrm{~mL}$ max. vol., diameter $14 \mathrm{~cm}$, depth $4.8 \mathrm{~cm}$ ) coloured with the different paints (Figure 2A). The standard $500 \mathrm{~mL}$ polypropylene soup bowls (Pro-Pac, Vechta, Germany) used as pan traps were painted with fluorescent or non-fluorescent blue, white, and yellow spray paints (Sparvar Leuchtfarbe, Spray-Color GmbH, Merzenich, Germany) following the protocol of by Reference [21] and dried over several weeks to 
remove any residual paint smell. Each pan trap was subsequently filled with about $400 \mathrm{~mL}$ of water. A few drops of odourless, liquid dishwashing detergent were added to break the surface tension of the water to increase insect capture [21].

Both fluorescent and non-fluorescent pan traps were simultaneously arranged in a circle, and the location of each individual pan trap within the circle was randomly allocated per set-up and site.. The pan traps were placed on the ground for $48 \mathrm{~h}$ (Figure 2C,D) following standard procedures $[14,16,21,23]$. Sampling was repeated every two weeks at each site for four repetitions. We stored the collected insects temporarily in 70\% ethanol and/or freezers before they were pinned for taxonomic identification.
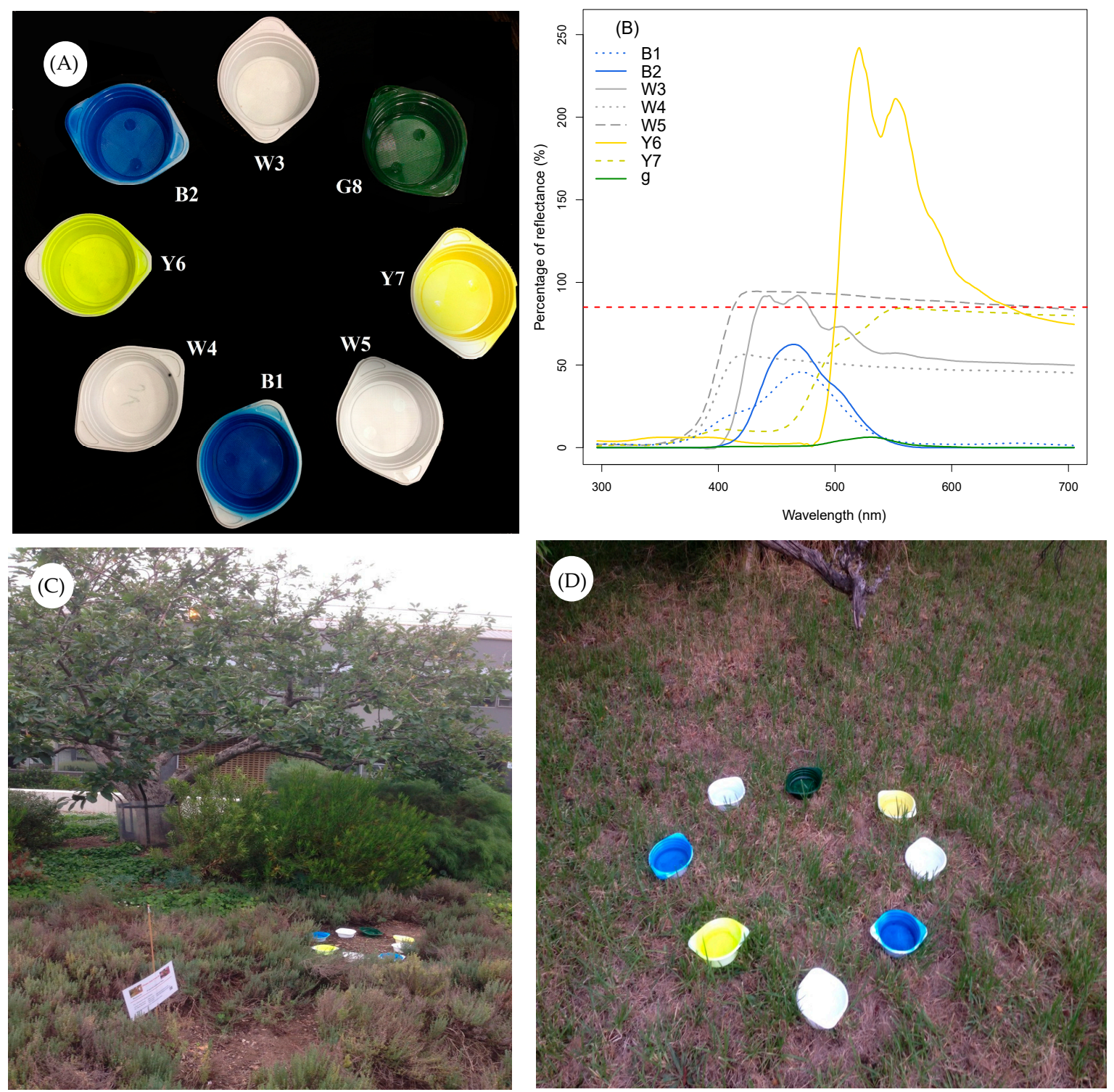

Figure 2. The pan trap experiment: (A) The pan trap bowls with eight different human perceived "colours", (B) the percentage of reflected radiation plotted against wavelength for each pan trap "colour" type (See Table 1 for details and the different treatments involved for each pan trap type). The red dotted line shows the $90 \%$ threshold for categorisation as fluorescent or non-fluorescent stimuli, (C,D) the pan traps in the sample field settings.

\subsection{Pan Trap Spectral Characterisation}

We measured the reflectance spectrum of each pan trap colour with a spectrophotometer fitted with quartz optics and a PX-2 pulsed xenon UV-visible radiation source (USB 2000+, 
Ocean Optics, Dunedin, FL, USA) that closely matches the spectral profile of typical daylight illumination [49]. The spectrophotometer was attached to a computer running SPECTRA SUITE software 2011 (see References [50,51] for additional details of spectral recording methods and procedures). The reflectance spectra of the eight different pan trap types are shown in Figure 2B. Pan traps reflecting more than $90 \%$ of incident radiation at any point across the spectrum were categorized as fluorescent since very few artificial [43] or natural flower surfaces typically reflect radiation above this level $[29,52]$. Whilst fluorescence may work in a variety of ways and produce weak changes in colour signalling [42], we use this definition in the current study to understand what pan trap features might influence the choices of insects.

\subsection{Insect Identification}

We identified all the collected insect specimens to the order level and some specimens to the genus level, using established protocols [53-58].

Table 1. List of the pan trap colours used in our data collection. The pan trap group (last column) in the table is categorized based on the spectral reflectance properties of each pan trap (Figure 2B).

\begin{tabular}{ccccc}
\hline \multicolumn{4}{c}{ Pan Trap Description } \\
\hline Stimuli & Treatments Involved & Paint & $\begin{array}{c}\text { Colour } \\
\text { (Human Perception) }\end{array}$ & Pan Trap Group \\
\hline B1 & Blue paint & Blue & Blue & Non-Fluorescent \\
B2 & Blue UV reflectance reduced & Blue "UV" fluorescent & Blue & Non-Fluorescent \\
W3 & White UV reflectance reduced & White "UV" fluorescent & White & Fluorescent \\
W4 & White paint & White & White & Fluorescent \\
W5 & White & White bowl without paint & White & Non-Fluorescent \\
Y6 & Yellow UV reflectance reduced & Yellow “UV" fluorescent & Yellow & Fluorescent \\
Y7 & Yellow paint & Yellow & Yellow & Non-Fluorescent \\
g8 & Green paint & Green & Green & Non-Fluorescent \\
\hline
\end{tabular}

\subsection{Data Analyses}

The data were recorded during the Australian summer to autumn 2016. The sampling periods spanned $48 \mathrm{~h}$.

We arranged the data in a $2 \times 2$ contingency table to test for a potential interaction between pan trap type, i.e., fluorescent or non-fluorescent, and the order of the insects captured using a Pearson chi-square test for independence. As part of the analyses we also calculated the standardised residuals for each entry of the contingency table [59]. All analyses were performed using the package "gmodels" [60] in the R programming language version 3.4.1 [61].

\section{Results}

When we considered the main research question, we found a significant interaction between the type of trap, either fluorescent or non-fluorescent, and the order of insect captured $\left(\chi^{2}=27.374\right.$, d.f. $=5$, $p<0.001$ ) (Figure 3). The main analysis was then followed by a residual analysis to identify those insect orders presenting significantly more or less captures than what is expected by chance (Table 2). This analysis revealed that Coleopterans (beetles) and Lepidopterans (butterflies or moths) were captured more frequently on fluorescent pan traps, whilst Dipterans (flies) were captured significantly less frequently in this type of pan trap (Figure 3, Table 2). Results are graphically summarised in Figure 3. 

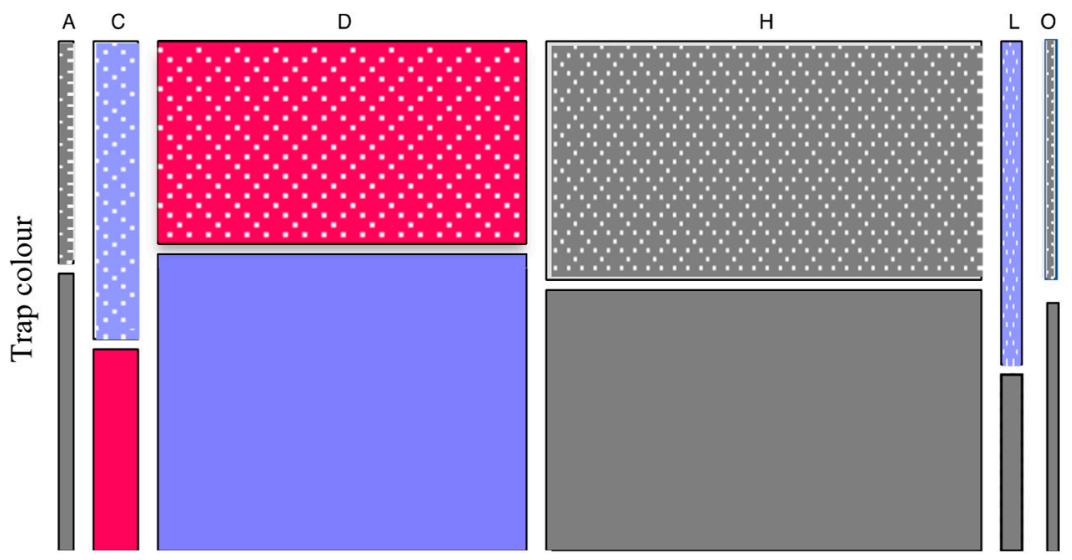

Standarized z-scores

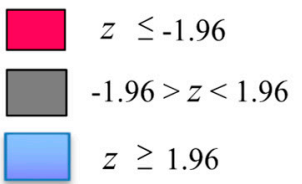

Figure 3. The mosaic plot shows the frequency of captures of the different insect types/order (coded with the following alphabetic letters for each group. H: Hymenoptera, D: Diptera, L: Lepidoptera, C: Coleoptera, O: Orthoptera, and A: Araneae. See Table 2 for details) for pan trap types classified as either fluorescent or non-fluorescent. The box width represents the proportion of captures for each insect order, whilst the box height is an indicator of the proportions of capture by the fluorescent pan traps (upper row dashed pattern) and the non-fluorescent traps (lower row solid pattern). The colour indicates the $z$-values for the respective standardized residuals (Table 2): blue indicates a significant preference for stimuli, red indicates that the stimuli collected significantly less individuals, and grey indicates the capture rate was not significantly different to the chance expectation (null condition). $\mathrm{F}=$ Fluorescent, $\mathrm{NF}=$ Non-Fluorescent.

Table 2. Summary of the $z$-scores and $p$-values for each insect order provided in Figure 3 for fluorescent and non-fluorescent pan traps. * indicates significant $p$-values at $\alpha=0.05$. $z$-scores $<0$ indicate a lower frequency of choices than those expected by chance. $z$-scores $\geq 0$ indicate a frequency of choices higher than expected by chance.

\begin{tabular}{ccc}
\hline \multirow{2}{*}{ Insect Order } & \multicolumn{2}{c}{ Pan Trap Type } \\
\cline { 2 - 3 } & Fluorescent Pan Traps & Non-Fluorescent Pan Traps \\
\cline { 2 - 3 } & $\mathbf{z}(p$-Value) & $\mathbf{z}(p$-Value) \\
\hline Hymenoptera & $0.981(0.327)$ & $-0.900(0.368)$ \\
Diptera & $-2.285(0.022)^{*}$ & $2.097(0.036)^{*}$ \\
Lepidoptera & $2.007(0.045)^{*}$ & $-1.842(0.065)$ \\
Coleoptera & $2.151(0.031)^{*}$ & $-1.973(0.048)^{*}$ \\
Orthoptera & $0.107(0.915)$ & $-0.098(0.922)$ \\
Araneae & $-0.112(0.911)$ & $0.103(0.918)$ \\
\hline
\end{tabular}

\section{Discussion}

Pan traps are a conventional way of assessing insect-flower visitor distributions [14-24]. Several studies advocate the use of fluorescent stimuli due to the assumed higher rates of insect captures $[14,17,21,62]$. Although pan trapping with non-fluorescent traps has been used in several studies $[16,41]$, it has rarely been considered whether the type of pan trap may bias the data collection of different insect orders due to the differences in colour processing among groups. We employed a combination of fluorescent and non-fluorescent pan trap stimuli and found that Hymenopteran insects have no significant preference for either the fluorescent or non-florescent pan traps. Other insect orders such as Coleoptera and Lepidoptera do show a preference for fluorescent pan traps (Figure 3, Table 2). In contrast, Dipterans (flies) demonstrated a preference for non-fluorescent stimuli. Our pan traps also collected some spiders (Araneae) and Orthopterans, although in relatively low numbers (Figure 3). Whilst these orders may have been an incidental by-catch, especially Orthoptera that may jump into the pan traps, these data were included in analyses as there is some evidence that Araneae and Orthoptera might participate in, or affect, pollination networks $[46,47]$. Neither of these orders 
showed any significant preference for pan traps. The evidence that Hymenopteran insects did not show a preference fits with the established literature that honeybees do not process stimulus intensity differences as a dimension of colour perception when making colour choices [63-67].

Currently, relatively little is known about the colour processing mechanisms of beetles, butterflies, and flies, but the spectral tuning of vision in insects of these orders is known [33-37] and might facilitate a capacity to process fluorescent signals [42]. Our data do suggest that such a possibility is worth exploring in detail with individual species from these insect orders. Such testing would also be of value with model bee species to validate whether indeed their visual system is insensitive to fluorescent signals as suggested by the current results.

To enable efficient censuses of insect pollinators in different environments, it is important to have a robust data collection method, and the use of fluorescent pan traps has been proposed to result in higher insect capture rate $[14,17,21,62]$. Our observations of nearby insects visiting flowering plants confirmed that many insects captured by our pan traps were also visiting flowers in the nearby plant communities and so may be potential pollinators (Figures 4 and 5) (personal observations by M.S., A.D., and A.G.D.).

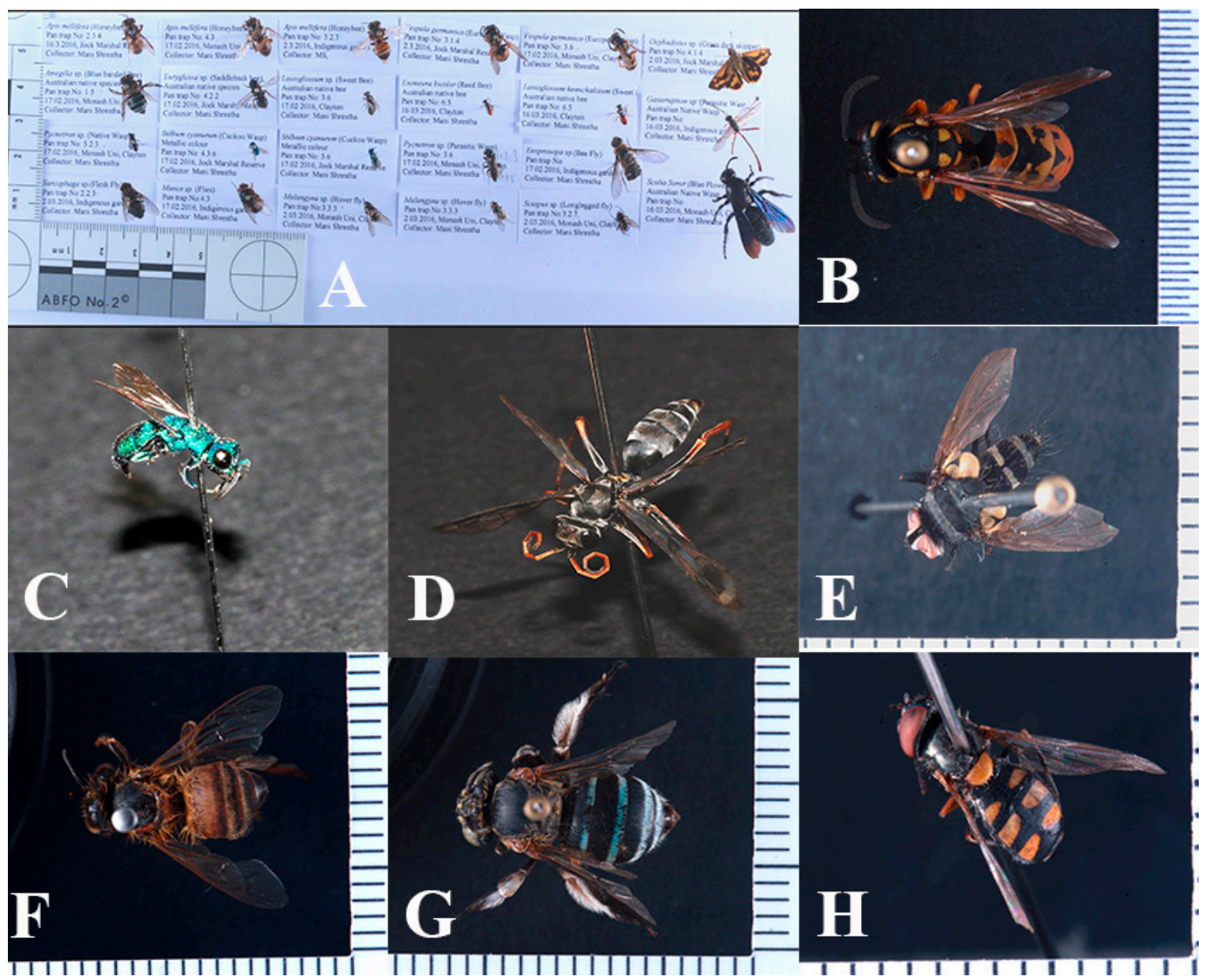

Figure 4. Sample insects captured by the pan traps: (A) Array of pinned insect samples, (B) European wasp (Vespula germanica), (C) cuckoo wasp (Stibum cyanurum), (D) male winged ant (Myrmecia urens), (E) long-legged fly (Sciapus sp.), (F) honey bee (Apis mellifera), (G) blue-banded bee (Amegilla sp.), and (H) hoverfly (Melagyna sp.). Images ${ }^{\circledR}$ Copyright M.S. and J.H.C.H. 


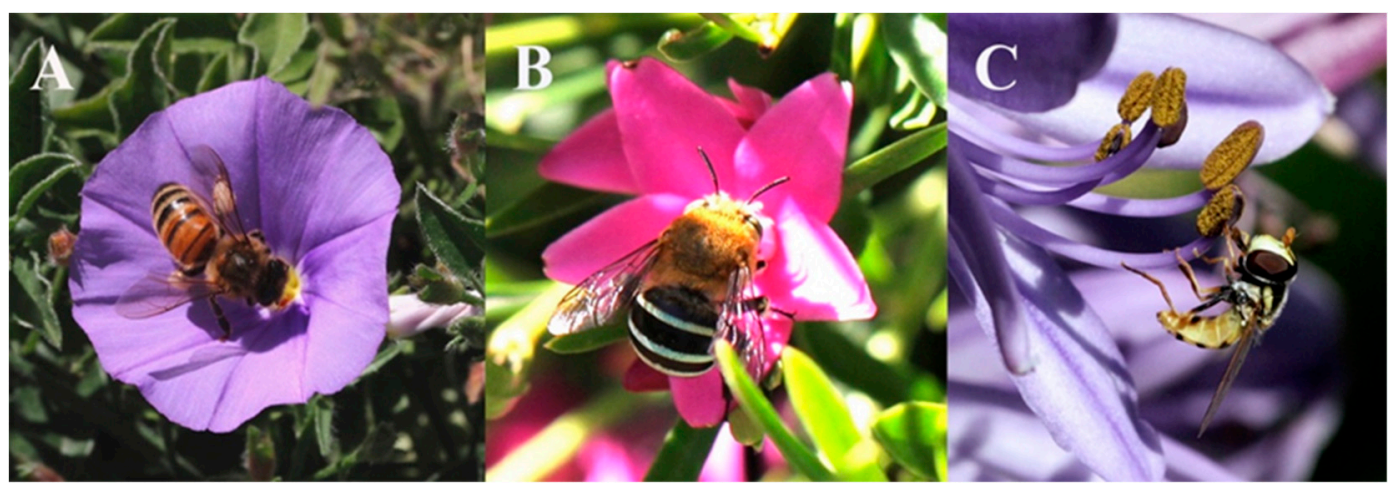

Figure 5. Colour photographs of flower visiting insects taken nearby the pan trap locations: (A) honey bee (Apis mellifera), (B) blue-banded bee (Amegilla sp.), (C) hoverfly (Melagyna sp.). Images Copyright ${ }^{\circledR}$ M.S.

The insects we captured included trichromatic native bees and introduced honeybees [68,69], hoverflies that are thought to have a four-colour visual system [34,70,71], native wasps that could potentially be trichromatic or tetrachromatic $[68,69]$, and beetles that currently have a poorly understood colour visual system [72-74]. Our data on insect capture rates with either fluorescent or non-fluorescent stimuli shows that the choice of respective stimuli may result in a biased distribution (Figure 3) of the relative abundances of different pollinator groups [29], although true bias is difficult to assess in outdoor experiments with free-flying insects where overall densities are typically unknown. Future work should dissect how the spectral profiles of coloured pan trap stimuli (Figure 2B) may be perceived by different insects and how the observed preferences might influence which flower colours are pollinated [28-30,75-77]. Corrections could then be estimated from the relative ratio of fluorescent and non-fluorescent capture rates as those shown in Figure 3, although preference effects may potentially vary between species within the insect orders (Tables S1 and S2) and so corrections would benefit longer term through validation testing with individual species. We acknowledge this is very difficult: so far, colour preference testing has been successfully performed with very few species [26-32,75-77].

\section{Conclusions}

We tested if fluorescent or non-fluorescent pan trap colours captured potential flower-visiting insects in a way that might be biased due to differences in how particular insect orders may process spectral information. Whilst for Hymenopteran species there was no significant difference in the frequency of individuals caught, flower-visiting flies were preferentially captured in non-fluorescent pan traps. In contrast, fluorescent pan traps captured significantly higher rates of beetles and Lepidopterans than non-fluorescent traps, suggesting that a fundamental difference in spectral processing may have influenced the insect capture by a particular pan trap. We, thus, suggest that to survey insect populations, care in interpretation is required in the selection of pan traps colours and that corrections should be considered when conducting meta-analyses on studies with different pan trap colours.

Supplementary Materials: The following are available online at http:/ /www.mdpi.com/2075-4450/10/2/40/s1, Table S1: Insect capture using pan traps, Table S2: A complete list of insect species sampled in this study, with numbers of individuals collected with pan traps (PT).

Author Contributions: A.N., T.T., M.S., and A.G.D. designed the experiment; M.S., A.D., S.R.H., and A.G.D. collected the data; M.S. and J.H.J.C. imaged the insects; J.E.G., A.G.D., and M.S. analysed the data; all the authors edited and revised the manuscript and approved for final submission.

Funding: This research was supported under Australian Research Council's Discovery projects funding scheme (project numbers DP160100161) for A.D. and A.G.D., from the MILJØ2015 program of the Research Council of Norway (project number 230279/E50, PolliClim) to A.N., T.T., and A.G.D. 
Acknowledgments: We thank Ricky San Martin and the Monash University School of Biological Sciences for providing access to the Jock Marshal Reserve to conduct the experiments. We acknowledge Zoë Bukovac and David Lea for helping to set up the pan trap experiments. We also thank Martin Burd, School of Biological Sciences, Monash University for providing the lab facilities and equipment required for this experiment. M.S. acknowledges a research award from the School of Media and Communication, RMIT University to facilitate part of this research. All the colour images are taken by M.S., and the insect images are taken by M.S. and J.H.J.C.

Conflicts of Interest: The authors declare that they have no conflict of interest involving the work reported here.

\section{References}

1. Klein, A.-M.; Vaissiere, B.E.; Cane, J.H.; Steffan-Dewenter, I.; Cunningham, S.A.; Kremen, C.; Tscharntke, T. Importance of pollinators in changing landscapes for world crops. Proc. R. Soc. Lond. B Biol. Sci. 2007, 274, 303-313. [CrossRef] [PubMed]

2. Goulson, D.; Lye, G.C.; Darvill, B. Decline and conservation of bumble bees. Annu. Rev. Entomol. 2008, 53, 191-208. [CrossRef] [PubMed]

3. Hegland, S.J.; Nielsen, A.; Lázaro, A.; Bjerknes, A.-L.; Totland, Ø. How does climate warming affect plant-pollinator interactions? Ecol. Lett. 2009, 12, 184-195. [CrossRef] [PubMed]

4. Winfree, R.; Aguilar, R.; Vázquez, D.P.; LeBuhn, G.; Aizen, M.A. A meta-analysis of bees' responses to anthropogenic disturbance. Ecology 2009, 90, 2068-2076. [CrossRef] [PubMed]

5. Potts, S.G.; Biesmeijer, J.C.; Kremen, C.; Neumann, P.; Schweiger, O.; Kunin, W.E. Global pollinator declines: Trends, impacts and drivers. Trends Ecol. Evol. 2010, 25, 345-353. [CrossRef] [PubMed]

6. Henry, M.; Beguin, M.; Requier, F.; Rollin, O.; Odoux, J.-F.; Aupinel, P.; Aptel, J.; Tchamitchian, S.; Decourtye, A. A common pesticide decreases foraging success and survival in honey bees. Science 2012, 336, 348-350. [CrossRef] [PubMed]

7. Vanbergen, A.J.; Initiative, I.P. Threats to an ecosystem service: Pressures on pollinators. Front. Ecol. Environ. 2013, 11, 251-259. [CrossRef]

8. Harrison, T.; Winfree, R. Urban drivers of plant-pollinator interactions. Funct. Ecol. 2015, 29, 879-888. [CrossRef]

9. Woodcock, B.A.; Isaac, N.J.B.; Bullock, J.M.; Roy, D.B.; Garthwaite, D.G.; Crowe, A.; Pywell, R.F. Impacts of neonicotinoid use on long-term population changes in wild bees in England. Nat. Commun. 2016, 7, 12459. [CrossRef]

10. Gallai, N.; Salles, J.-M.; Settele, J.; Vaissière, B.E. Economic valuation of the vulnerability of world agriculture confronted with pollinator decline. Ecol. Econ. 2009, 68, 810-821. [CrossRef]

11. Kjøhl, M.; Nielsen, A.; Stenseth, N.C. Potential Effects of Climate Change on Crop Pollination; Food and Agriculture Organization of the United Nations (FAO): Rome, Italy, 2011; ISBN 925106878X.

12. Potts, S.G.; Imp, V.L.; Ngo, H.T.; Biesmeijer, J.C.; Breeze, T.D.; Dicks, L.V.; Garibaldi, L.A.; Hill, R.; Settele, J.; Vanbergen, A.J.; et al. IPBES Summary for Policymakers of the Assessment Report of the Intergovernmental Science-Policy Platform on Biodiversity and Ecosystem Services on Pollinators, Pollination and Food Production; IPBES: Bonn, Germany, 2016; pp. 1-36.

13. Kirk, W.D.J. Ecologically seIective coIoured traps. Ecol. Entomol. 1984, 9, 35-41. [CrossRef]

14. Westphal, C.; Bommarco, R.; Carré, G.; Lamborn, E.; Morison, N.; Petanidou, T.; Potts, S.G.; Roberts, S.P.M.; Szentgyörgyi, H.; Tscheulin, T. Measuring bee diversity in different European habitats and biogeographical regions. Ecol. Monogr. 2008, 78, 653-671. [CrossRef]

15. Fortel, L.; Henry, M.; Guilbaud, L.; Guirao, A.L.; Kuhlmann, M.; Mouret, H.; Rollin, O.; Vaissière, B.E. Decreasing abundance, increasing diversity and changing structure of the wild bee community (Hymenoptera: Anthophila) along an urbanization gradient. PLoS ONE 2014, 9, e104679. [CrossRef] [PubMed]

16. Joshi, N.K.; Leslie, T.; Rajotte, E.G.; Kammerer, M.A.; Otieno, M.; Biddinger, D.J. Comparative trapping efficiency to characterize bee abundance, diversity, and community composition in apple orchards. Ann. Entomol. Soc. Am. 2015, 108, 785-799. [CrossRef]

17. Moreira, E.F.; da Silva Santos, R.L.; Penna, U.L.; Angel-Coca, C.; de Oliveira, F.F.; Viana, B.F. Are pan traps colors complementary to sample community of potential pollinator insects? J. Insect Conserv. 2016, 20, 583-596. [CrossRef] 
18. Lebuhn, G.; Droege, S.; Connor, E.F.; Gemmill-Herren, B.; Potts, S.G.; Minckley, R.L.; Griswold, T.; Jean, R.; Kula, E.; Roubik, D.W.; et al. Detecting Insect Pollinator Declines on Regional and Global Scales. Conserv. Biol. 2013, 27, 113-120. [CrossRef] [PubMed]

19. Droege, S.; Tepedino, V.J.; Lebuhn, G.; Link, W.; Minckley, R.L.; Chen, Q.; Conrad, C. Spatial patterns of bee captures in North American bowl trapping surveys. Insect Conserv. Divers. 2010, 3, 15-23. [CrossRef]

20. Bates, A.J.; Sadler, J.P.; Fairbrass, A.J.; Falk, S.J.; Hale, J.D.; Matthews, T.J. Changing bee and hoverfly pollinator assemblages along an urban-rural gradient. PLOS ONE 2011, 6, e23459. [CrossRef]

21. Nielsen, A.; Steffan-Dewenter, I.; Westphal, C.; Messinger, O.; Potts, S.G.; Roberts, S.P.M.; Settele, J.; Szentgyörgyi, H.; Vaissière, B.E.; Vaitis, M. Assessing bee species richness in two Mediterranean communities: Importance of habitat type and sampling techniques. Ecol. Res. 2011, 26, 969-983. [CrossRef]

22. LeBuhn, G.; Droege, S.; Connor, E.; Gemmill-Herren, B.; Azzu, N. Protocol to Detect and Monitor Pollinator Communities: Guidance for Practitioners; Food and Agriculture Organization (FAO): Rome, Italy, 2016.

23. Saunders, M.E.; Luck, G.W. Pan trap catches of pollinator insects vary with habitat. Aust. J. Entomol. 2013, 52, 106-113. [CrossRef]

24. Spafford, R.D.; Lortie, C.J. Sweeping beauty: Is grassland arthropod community composition effectively estimated by sweep netting? Ecol. Evol. 2013, 3, 3347-3358. [CrossRef] [PubMed]

25. Kevan, P.G.; Chittka, L.; Dyer, A.G. Limits to the salience of ultraviolet: Lessons from colour vision in bees and birds. J. Exp. Biol. 2001, 204, 2571-2580. [PubMed]

26. Raine, N.E.; Chittka, L. The adaptive significance of sensory bias in a foraging context: Floral colour preferences in the bumblebee Bombus terrestris. PLoS ONE 2007, 2, e556. [CrossRef] [PubMed]

27. Kemp, D.J.; Herberstein, M.E.; Fleishman, L.J.; Endler, J.A.; Bennett, A.T.D.; Dyer, A.G.; Hart, N.S.; Marshall, J.; Whiting, M.J. An integrative framework for the appraisal of coloration in nature. Am. Nat. 2015, 185, 705-724. [CrossRef] [PubMed]

28. Koethe, S.; Bossems, J.; Dyer, A.G.; Lunau, K. Colour is more than hue: Preferences for compiled colour traits in the stingless bees Melipona mondury and M. quadrifasciata. J. Comp. Physiol. A 2016, 202, 615-627. [CrossRef] [PubMed]

29. Van der Kooi, C.J.; Dyer, A.G.; Kevan, P.G.; Lunau, K. Functional significance of the optical properties of flowers for visual signalling. Ann. Bot. 2018. [CrossRef] [PubMed]

30. Ostroverkhova, O.; Galindo, G.; Lande, C.; Kirby, J.; Scherr, M.; Hoffman, G.; Rao, S. Understanding innate preferences of wild bee species: Responses to wavelength-dependent selective excitation of blue and green photoreceptor types. J. Comp. Physiol. A 2018, 204, 667-675. [CrossRef]

31. Dyer, A.G.; Paulk, A.C.; Reser, D.H. Colour processing in complex environments: Insights from the visual system of bees. Proc. R. Soc. Lond. B Biol. Sci. 2011, 278, 952-959. [CrossRef]

32. Yilmaz, A.; Dyer, A.G.; Rössler, W.; Spaethe, J. Innate colour preference, individual learning and memory retention in the ant Camponotus blandus. J. Exp. Biol. 2017, 220, 3315-3326. [CrossRef]

33. Stavenga, D. Colour in the eyes of insects. J. Comp. Physiol. A 2002, 188, 337-348.

34. Lunau, K. Visual ecology of flies with particular reference to colour vision and colour preferences. J. Comp. Physiol. A 2014, 200, 497-512. [CrossRef] [PubMed]

35. Arikawa, K.; Inokuma, K.; Eguchi, E. Pentachromatic visual system in a butterfly. Naturwissenschaften 1987, 74, 297-298. [CrossRef]

36. Wakakuwa, M.; Stavenga, D.G.; Kurasawa, M.; Arikawa, K. A unique visual pigment expressed in green, red and deep-red receptors in the eye of the small white butterfly, Pieris rapae crucivora. J. Exp. Biol. 2004, 207, 2803-2810. [CrossRef] [PubMed]

37. Briscoe, A.D. Reconstructing the ancestral butterfly eye: Focus on the opsins. J. Exp. Biol. 2008, 211, 1805-1813. [CrossRef] [PubMed]

38. Jacobs, G.H. Photopigments and the dimensionality of animal color vision. Neurosci. Biobehav. Rev. 2018, 86, 108-130. [CrossRef] [PubMed]

39. Leong, J.M.; Thorp, R.W. Colour-coded sampling: The pan trap colour preferences of oligolectic and nonoligolectic bees associated with a vernal pool plant. Ecol. Entomol. 1999, 24, 329-335. [CrossRef]

40. Toler, T.R.; Evans, E.W.; Tepedino, V.J. Pan-trapping for bees (Hymenoptera: Apiformes) in Utah's West Desert: The importance of color diversity. Pan Pac. Entomol. 2005, 81, 103-113.

41. Sircom, J.; Jothi, G.A.; Pinksen, J. Monitoring bee populations: Are eusocial bees attracted to different colours of pan trap than other bees? J. Insect Conserv. 2018, 22, 1-9. [CrossRef] 
42. Marshall, J.; Johnsen, S. Fluorescence as a means of colour signal enhancement. Phil. Trans. R. Soc. B 2017, 372, 20160335. [CrossRef]

43. Wyszecki, G.; Stiles, W.S. Color Science, 2nd ed.; John Wiley \& Sons: Hoboken, NJ, USA, 1982.

44. Heiling, A.M.; Herberstein, M.E.; Chittka, L. Pollinator attraction: Crab-spiders manipulate flower signals. Nature 2003, 421, 334. [CrossRef]

45. Huey, S.; Nieh, J.C. Foraging at a safe distance: Crab spider effects on pollinators. Ecol. Entomol. 2017, 42, 469-476. [CrossRef]

46. Jackson, R.R.; Pollard, S.D.; Nelson, X.J.; Edwards, G.B.; Barrion, A.T. Jumping spiders (Araneae: Salticidae) that feed on nectar. J. Zool. 2001, 255, 25-29. [CrossRef]

47. Micheneau, C.; Fournel, J.; Warren, B.H.; Hugel, S.; Gauvin-Bialecki, A.; Pailler, T.; Strasberg, D.; Chase, M.W. Orthoptera, a new order of pollinator. Ann. Bot. 2010, 105, 355-364. [CrossRef] [PubMed]

48. R Core Team. R: A Language and Environment for Statistical Computing; R Foundation for Statistical Computing: Vienna, Austria, 2018; version 3.5.1. Available online: https:/ / www.R-project.org/ (accessed on 22 January 2018).

49. Dyer, A.G.; Chittka, L. Biological significance of distinguishing between similar colours in spectrally variable illumination: Bumblebees (Bombus terrestris) as a case study. J. Comp. Physiol. A 2004, 190, 105-114. [CrossRef] [PubMed]

50. Dyer, A.G.; Boyd-Gerny, S.; McLoughlin, S.; Rosa, M.G.P.; Simonov, V.; Wong, B.B.M. Parallel evolution of angiosperm colour signals: Common evolutionary pressures linked to hymenopteran vision. Proc. R. Soc. Lond. B Biol. Sci. 2012, 279, 3606-3615. [CrossRef] [PubMed]

51. Shrestha, M.; Dyer, A.G.; Boyd-Gerny, S.; Wong, B.B.M.; Burd, M. Shades of red: Bird-pollinated flowers target the specific colour discrimination abilities of avian vision. New Phytol. 2013, 198, 301-310. [CrossRef]

52. Van der Kooi, C.J.; Elzenga, J.T.M.; Staal, M.; Stavenga, D.G. How to colour a flower: On the optical principles of flower coloration. Proc. R. Soc. B Biol. Sci. 2016, 283. [CrossRef]

53. Michener, C.D. The Bees of the World, 2nd ed.; Johns Hopkins: Baltimore, MD, USA, 2007.

54. Zborowski, P.; Storey, R. Field Guide to Insects in Australia; New Holland Publisher; CSIRO: Canberra, Australia, 2010; ISBN 0730104141.

55. Dollin, A.; Batley, M.; Robinson, M.; Faulkner, B. Native Bees of the Sydney Region, a Field Guide; Australian Native Bee Research Centre: Richmond, Australia, 2000.

56. Gullan, P.J.; Cranston, P.S. The Insects: An Outline of Entomology; John Wiley \& Sons: Hoboken, NJ, USA, 2014; ISBN 111884615X.

57. Marshall, S.A. Flies the Natural History E Diversity of Diptera; Firefly Books: Richmond Hill, ON, USA, 2012; ISBN 1770851003.

58. Kuiter, R.H. Orchid Pollinators of Victoria; Aquatic Photographics: Seaford, Australia, 2016.

59. Faraway, J.J. Extending the Linear Model with R; Carlin, B.P., Chatfield, C., Tanner, M., Zidek, J., Eds.; Chapman \& Hall/CRC: Boca Raton, FL, USA, 2006.

60. Warnes, G.R.; Bolker, B.; Lumley, T.; Johnson, R.C. gmodels: Various R Programming tools for Model Fitting; Incl. R source Code and/or Doc. Contrib. by Bolker, B., Lumley, T., Johnson, R.C.; Version 2.18.1; R Core Team: Vienna, Austria, 2018; pp. 1-20.

61. R Development Core Team. R Development Core Team: R: A Language and Environment for Statistical Computing. 2017. Available online: http:/ / www.r-project.org (accessed on 22 January 2018).

62. Vrdoljak, S.M.; Samways, M.J. Optimising coloured pan traps to survey flower visiting insects. J. Insect Conserv. 2012, 16, 345-354. [CrossRef]

63. Daumer, K. Reizmetrische untersuchung des Farbensehens der Bienen. Z. Vgl. Physiol. 1956, 38, 413-478.

64. Menzel, R. Achromatic vision in the honeybee at low light intensities. J. Comp. Physiol. 1981, 141, $389-393$. [CrossRef]

65. Brandt, R.; Backhaus, W.; Dittrich, M.; Menzel, R. Simulation of threshold spectral sensitivity according to the color theory for the honeybee. In Gene-Brain Behaviour, Proceedings of the 21st Göttingen Neurobiology Conference, Thieme, Stuttgart; Georg Thieme Verlag: Göttingen, Germany, 1993; Volume 122, p. 374.

66. Backhaus, W. Color vision and color choice behavior of the honey bee. Apidologie 1993, 24, 309-331. [CrossRef]

67. Ng, L.; Garcia, J.E.; Dyer, A.G. Why colour is complex: Evidence that bees perceive neither brightness nor green contrast in colour signal processing. Facets 2018, 3, 800-817. [CrossRef] 
68. Peitsch, D.; Fietz, A.; Hertel, H.; de Souza, J.; Ventura, D.F.; Menzel, R. The spectral input systems of hymenopteran insects and their receptor-based colour vision. J. Comp. Physiol. A 1992, 170, 23-40. [CrossRef] [PubMed]

69. Briscoe, A.D.; Chittka, L. The evolution of color vision in insects. Annu. Rev. Entomol. 2001, 46, 471-510. [CrossRef]

70. Troje, N. Spectral categories in the learning behaviour of blowflies. Z. Naturforsch. C 1993, 48, 96-104. [CrossRef]

71. Shrestha, M.; Lunau, K.; Dorin, A.; Schulze, B.; Bischoff, M.; Burd, M.; Dyer, A.G. Floral colours in a world without birds and bees: The plants of Macquarie Island. Plant Biol. 2016, 18, 842-850. [CrossRef] [PubMed]

72. Dafni, A.; Bernhardt, P.; Shmida, A.; Ivri, Y.; Greenbaum, S.; O’Toole, C.; Losito, L. Red bowl-shaped flowers: Convergence for beetle pollination in the Mediterranean region. Isr. J. Plant Sci. 1990, 39, 81-92.

73. Martínez-Harms, J.; Vorobyev, M.; Schorn, J.; Shmida, A.; Keasar, T.; Homberg, U.; Schmeling, F.; Menzel, R. Evidence of red sensitive photoreceptors in Pygopleurus israelitus (Glaphyridae: Coleoptera) and its implications for beetle pollination in the southeast Mediterranean. J. Comp. Physiol. A 2012, 198, 451-463. [CrossRef]

74. Arnold, S.E.J.; Stevenson, P.C.; Belmain, S.R. Shades of yellow: Interactive effects of visual and odour cues in a pest beetle. PeerJ 2016, 4, e2219. [CrossRef]

75. Raine, N.E.; Ings, T.C.; Dornhaus, A.; Saleh, N.; Chittka, L. Adaptation, genetic drift, pleiotropy, and history in the evolution of bee foraging behavior. Adv. Stud. Behav. 2006, 36, 305-354.

76. Morawetz, L.; Svoboda, A.; Spaethe, J.; Dyer, A.G. Blue colour preference in honeybees distracts visual attention for learning closed shapes. J. Comp. Physiol. A 2013, 199, 817-827. [CrossRef] [PubMed]

77. Papiorek, S.; Rohde, K.; Lunau, K. Bees' subtle colour preferences: How bees respond to small changes in pigment concentration. Naturwissenschaften 2013, 100, 633-643. [CrossRef] [PubMed]

(C) 2019 by the authors. Licensee MDPI, Basel, Switzerland. This article is an open access article distributed under the terms and conditions of the Creative Commons Attribution (CC BY) license (http://creativecommons.org/licenses/by/4.0/). 